\title{
Coimmobilized Microalgae and Nitrifying Bacteria for Ammonium Removal
}

\author{
Xue Bai, Haixin Gu, and Yulong Li
}

\begin{abstract}
Coimmobilization of the freshwater microalgae in alginate beads with the microalgae bacterium under continuous synthetic wastewater culture conditions significantly removed ammonium ions efficiently. It is proposed that coimmobilization of a microalgae with microalgae bacteria can serve as a tool in devising novel wastewater treatments.
\end{abstract}

Index Terms-Ammonium removal, microbial immobilization, microalgae, wastewater treatments.

\section{INTRODUCTION}

Ammonium is toxic to aquatic species and causes eutrophication in natural water environments [1], [2]. The low maximum growth rates and growth yields of nitrifying bacteria make it difficult to obtain and maintain sufficient nitrifying bacteria in traditional wastewater treatment plants [3]. It has been pointed out that the immobilization of nitrifying bacteria to an appropriate carrier material is a feasible method to overcome the problem associated with the low growth rate constants of nitrifying bacteria [4]. Considering that there are few researches about ammonium degradation by co-immobilized micro-algae and nitrifying bacteria, this study was designed to investigate the characteristic and kinetic behavior of using mixed micro-algae and nitrifying bacteria immobilized onto microporous carrier and to determine the kinetic constants in ammonium removal process.

\section{MATERIALS AND METHODS}

\section{A. Immobilization Method}

Microalgae and nitrifying bacteria was obtained from an aeration sludge tank of the Lanzhou (China) Petrochemical Sewage Treatment Plant. The composition of the inorganic medium used for the growth of microorganisms was (in $\mathrm{g} \mathrm{L}^{-1}$ ): $\mathrm{NH}_{4} \mathrm{HCO}_{3} \quad 0.564, \mathrm{MgSO}_{4} \cdot 7 \mathrm{H}_{2} \mathrm{O} \quad 0.380, \mathrm{CaCl}_{2} \cdot 2 \mathrm{H}_{2} \mathrm{O} \quad 0.020$ and $\mathrm{K}_{2} \mathrm{HPO}_{4}$ 0.087. The microorganisms' suspension (microalgae and nitrifying bacteria) and culture medium (200 $\mathrm{ml}$ synthetic wastewater) were added to a $500 \mathrm{ml}$ conical flask containing sterilized $4 \mathrm{~g}$ polypropylene carrier. The flask was kept on a rotary shaker for 15 days at $140 \mathrm{rpm}$.

\section{B. Analytical Methods}

Ammonium content was measured using standard water

Manuscript received May 1, 2015; revised July 31, 2015.

The authors are with Key Laboratory of Integrated Regulation and Resource Development on Shallow Lake of Ministry of Education, College of Environment, Hohai University, Nanjing 210098, China (e-mail: baixue@hhu.edu.cn, ghxhhu@gmail.com, liyulong19910912@sina.com). analysis methods.

\section{Morphological Observation}

The samples were subsequently cut with a sterile scalpel, coated with gold, and examined using a scanning electron microscope (S-520 SEM, Hitachi, Japan).

\section{RESULTS AND DisCUSSION}

\section{A. Factors Influencing of Ammonium Removal}

In stirred batch experiments, effects of processing parameters were showed in Fig. 1. C/N ratio is one of the most critical parameters of the ammonium removal process, for it directly influences the growth competition between autotrophic (nitrifying bacteria) and heterotrophic (denitrifying bacteria) microorganism populations. Fig. 1a) presents the ammonium concentrations decrease along with increasing reaction times and decrease currents were similar at the beginning 4 hours. However, the effect of $\mathrm{C} / \mathrm{N}$ ratio on ammonium removal appeared at the latter 4 hours: the ammonium concentration was almost no change (about $15 \mathrm{mg}$ $\mathrm{L}^{-1}$ ) during the following 4 hours at $\mathrm{C} / \mathrm{N}$ ratio was $3.4 \mathrm{~g} \mathrm{COD}$ $\mathrm{g} \mathrm{N}^{-1}$; whereas the ammonium concentrations were decreased to $11 \mathrm{mg} \mathrm{L}^{-1}\left(\mathrm{C} / \mathrm{N}=6.0 \mathrm{~g} \mathrm{COD} \mathrm{g} \mathrm{N}^{-1}\right)$ and $7 \mathrm{mg} \mathrm{L}^{-1}(\mathrm{C} / \mathrm{N}=10.8$

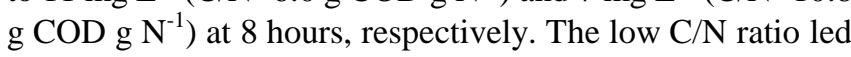
total nitrogen removal efficiency to a low value. This phenomenon seems to be caused by the lack of organic compounds for use as an electron donor in denitrification [5]. The $\mathrm{C} / \mathrm{N}$ ratio required for the denitrification can be determined by denitrification process stoichiometry and organic matter composition. It has been shown that $\mathrm{NH}_{4}{ }^{+} \mathrm{N}$ could reach maximum rate of elimination at value 10.8 of $\mathrm{C} / \mathrm{N}$ ratio. The stoichiometric requirement for denitrification is 4.2 g COD $\mathrm{g} \mathrm{N}^{-1}$ [6]. The excrescent organic matter supplied to the system might be consumed by oxidation or assimilation but not during the denitrification process. 2)It has often been found that DO is one of the most important factors affecting nitrification performance [7]. Fig. 1b) indicates that the slope of ammonium reduction curve at DO up to $2.0 \mathrm{mg} \mathrm{L}^{-1}$ is significantly smaller than that at higher DO concentrations. This is because when DO was at low concentration, oxidization of ammonium was limited in the nitrification process. Therefore, the optimum DO concentration for ammonium removal in this system is $4.0 \mathrm{mg} \mathrm{L}^{-1}$. It can be seen that the proper DO is $6.0 \mathrm{mg} / \mathrm{L}$, and the high removal rates of $\mathrm{NH}_{4}{ }^{+} \mathrm{N}$ can be achieved under this condition. 3)The influence of temperature over ammonium removal process is important for bioreactor design and operation. Fig. 1c) shows that ammonium concentration was more quickly degraded $25{ }^{\circ} \mathrm{C}$ than at any other temperature. According to Arrhenius 
Equation, the activation energy in this process was $35.9 \mathrm{KJ}$ $\mathrm{mol}^{-1}$, which was between that in single stage biodenitrification process, $28.6 \mathrm{KJ} \mathrm{mol}^{-1}$, and that in oxidizing nitrite by immobilized nitrifying cells, $63.6 \mathrm{KJ}$ $\mathrm{mol}^{-1}$ [8]. For these reasons, $25^{\circ} \mathrm{C}$ should be selected as the optimal temperature for immobilized microorganism. Plants designed for ammonium removal should be based on the expected temperature. 4)pH value is a key factor in microbial metabolic processes, because it influences the redox-potential and the enzymatic activity. Fig. 1d) shows the effects at various $\mathrm{pH}$ values in the range of 6.0-9.0 on performance of ammonium removal bioreactor. The slopes of the ammonium reduction curve at influent $\mathrm{pH}$ values up to 8.0 and 9.0 are sharper than that at the lower $\mathrm{pH}$ value. The optimal $\mathrm{pH}$ of immobilized microorganism was 8.0, and the similar result was reported previously [9].
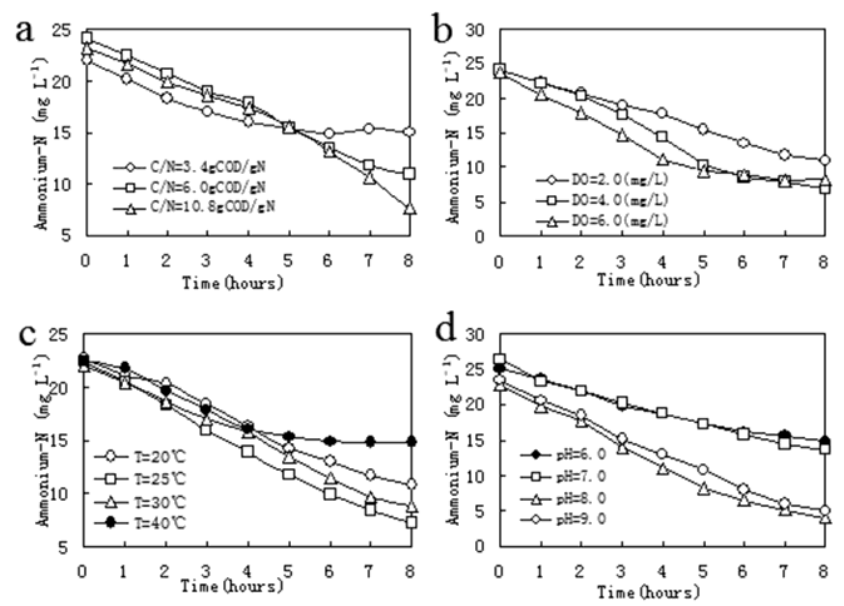

Fig. 1. Effects of (a) $\mathrm{C} / \mathrm{N}$, (b) DO, (c) temperature, (d) $\mathrm{pH}$ on the removal of ammonium.

\section{B. The First-Order Kinetics Study}

In this set of stirred batch experiments, the first-order kinetics is used to simulate the nitrification process in order to determine the ammonium removal viability on various water quality parameters. The carriers with immobilized microorganisms in the bioreactor were floated in the stirred batch reactor. The kinetics of ammonium degradation can be simulated by using first-order kinetics:

$$
\frac{d S}{d t}=-k S
$$

$S$ : substrate concentration $\left(\mathrm{mg} \mathrm{L}^{-1}\right) ; k$ : substrate removal rate constant $\left(\mathrm{h}^{-1}\right)$.

The equation used in the integrating algorithm within one time step is:

$$
S=\frac{S_{0}}{e^{k t}}
$$

The substrate removal rate constant is given by:

$$
k=\frac{\ln \frac{S_{0}}{S}}{t}
$$

In the various conditions of water quality parameters, such as $\mathrm{C} / \mathrm{N}, \mathrm{DO}$, temperatures and $\mathrm{pH}$, the ammonium removal rate constants $k$ can be calculated by using (3). The values of $k$ and substrate removal rate constant are summarized in Table I. The relative coefficient $\left(r^{2}\right)$ values from the analysis suggest that the kinetics of the reactions were almost linear, so it is feasible to use the first-order kinetics to determine the viability of the nitrification process. According to table I, the ammonia-nitrogen degradation rate constant $(K)$ is $0.0952 \mathrm{~h}^{-1}$ when $\mathrm{C} / \mathrm{N}$ at 6.0 ; it reached $0.1556 \mathrm{~h}^{-1}$ when dissolved oxygen was 4.0. however, when dissolved oxygen was larger than 4.0, the $K$ value changed little, the $K$ value was between 0.0910 and $0.1355 \mathrm{~h}^{-1}$ when the temperatur between 20 and $30{ }^{\circ} \mathrm{C}$, while it dropped to $0.0634 \mathrm{~h}^{-1}$ at $40{ }^{\circ} \mathrm{C}$. Therefore, room temperature can be suitable for denitrification reaction. In addition, $\mathrm{pH}$ value made a greater impact in ammonia nitrogen degradation rate constant, which reaches the maximum value $\left(0.2054 \mathrm{~h}^{-1}\right)$ when $\mathrm{pH}$ was 8.0 . Therefore, the appropriate $\mathrm{pH}$ should be 8.0 .

\begin{tabular}{|c|c|c|c|c|}
\hline Parameters & Condition & Unit & $K\left(\mathrm{~h}^{-1}\right)$ & $r^{2}$ \\
\hline \multirow[t]{3}{*}{ Influent $\mathrm{C} / \mathrm{N}$} & 3.4 & g COD g N-1 & 0.059 & 0.779 \\
\hline & 6.0 & g COD g N-1 & 0.095 & 0.976 \\
\hline & 10.8 & $\mathrm{~g} \mathrm{COD} \mathrm{g} \mathrm{N}^{-1}$ & 0.108 & 0.881 \\
\hline \multirow[t]{3}{*}{ DO } & 2.0 & $\mathrm{mg} \mathrm{L}^{-1}$ & 0.095 & 0.976 \\
\hline & 4.0 & $\mathrm{mg} \mathrm{L}^{-1}$ & 0.155 & 0.956 \\
\hline & 6.0 & $\mathrm{mg} \mathrm{L}^{-1}$ & 0.155 & 0.943 \\
\hline \multirow[t]{4}{*}{ Temperature } & 20 & ${ }^{\circ} \mathrm{C}$ & 0.091 & 0.978 \\
\hline & 25 & ${ }^{\mathrm{o}} \mathrm{C}$ & 0.135 & 0.985 \\
\hline & 30 & ${ }^{\mathrm{o}} \mathrm{C}$ & 0.107 & 0.971 \\
\hline & 40 & ${ }^{\mathrm{o}} \mathrm{C}$ & 0.063 & 0.900 \\
\hline \multirow[t]{4}{*}{ Influent pH } & 6.0 & & 0.069 & 0.989 \\
\hline & 7.0 & & 0.085 & 0.992 \\
\hline & 8.0 & & 0.205 & 0.977 \\
\hline & 9.0 & & 0.179 & 0.964 \\
\hline
\end{tabular}

TABLE I: VALUES OF PARAMETERS AND RELATED AMMONIUM REMOVAL RATE CONSTANTS $K$

\section{Michaelis-Menten Kinetic Study}

The ammonium removal process could also be considered as a simple enzyme-catalyzed reaction with one substrate and without product inhibition [10]. A simple but plausible steady-state model has been used to predict the biodegradation rate in batch experiment. The most common kinetics for biological substrate uptake is the Michaelis-Menten equation:

$$
v=-\frac{d S}{d t}=\frac{v \max S}{K_{m}+S}
$$

where $v$ is the substrate removal rate, $v_{\max }$ is the maximum growth rate, $K_{m}$ is the saturation coefficient and $S$ is the 
substrate concentration. With regarding to reactor design, $v_{\max }$ contains the necessary information about the limit of the maximum load, whereas $K_{m}$ describes the achievable effluent quality for a specific substrate.

TABLE II: VALUES OF PARAMETERS AND RELATED CALCULATIONS OF STIRRED BATCH EXPERIMENT

\begin{tabular}{|c|c|c|c|c|c|c|c|c|}
\hline $\begin{array}{c}t \\
(\mathrm{~h})\end{array}$ & $\begin{array}{c}S \\
\left(\mathrm{mg} \cdot \mathrm{L}^{-1}\right.\end{array}$ & $\frac{\ln \frac{S_{o}}{S}}{S_{o}-S}$ & $\frac{t}{S_{o}-S}$ & $v_{m}=\frac{v_{\max } S}{K_{m}+S}$ & $v_{k}$ & $v_{e}$ & $\frac{v_{e}-v_{m}}{v_{e} \times 100 \%}$ & $\frac{v_{e}-v_{k}}{v_{e}} \times 100 \%$ \\
\hline 0 & 24.13 & 0.045 & 0.237 & 4.1938 & 5.914 & 4.541 & 7.6 & -30.2 \\
\hline 1 & 19.91 & 0.050 & 0.256 & 3.8512 & 4.880 & 3.904 & 1.4 & -25.0 \\
\hline 2 & 16.32 & 0.055 & 0.272 & 3.4924 & 4.000 & 3.348 & -4.3 & -19.4 \\
\hline 3 & 13.12 & 0.060 & 0.295 & 3.1015 & 3.215 & 2.875 & -7.9 & -11.9 \\
\hline 4 & 10.61 & 0.068 & 0.312 & 2.7325 & 2.600 & 2.482 & -10.0 & -4.7 \\
\hline 5 & 8.14 & 0.076 & 0.333 & 2.2987 & 1.995 & 2.172 & -5.8 & 8.2 \\
\hline 6 & 6.11 & 0.086 & 0.353 & 1.8741 & 1.497 & 1.943 & 3.6 & 22.9 \\
\hline 7 & 4.31 & 0.105 & 0.369 & 1.4313 & 1.056 & 1.795 & 20.3 & 41.2 \\
\hline 8 & 2.49 & 0.045 & 0.237 & 0.9024 & 0.610 & 1.730 & 47.8 & 64.7 \\
\hline
\end{tabular}

Note: The unit of $v_{m}, v_{k}$ and $v_{e}$ is $\mathrm{mg} \mathrm{L}^{-1} \mathrm{~s}^{-1}$.

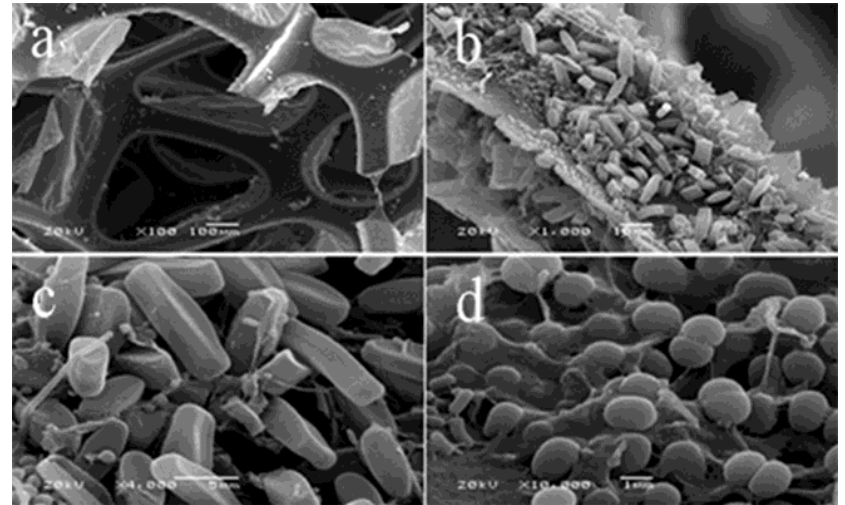

Fig. 2. SEM of carrier and microorganisms' morphology: (a) 100× carrier, (b) $1,000 \times$ carrier with micro-algae and nitrifying bacteria, (c) 4,000× carrier with micro-algae and (d) $10,000 \times$ carrier with nitrifying bacteria.

The effect of internal diffusion on the overall rate should be negligible, in respect that the macroporous structure (pore size $\approx 1 \mathrm{~mm}$ ) carriers have optimum mass transfer performance in the experiment. Therefore, the limiting rate process is chemical reaction. Hence, determined kinetics constants by operating experiment with immobilized microorganisms in the bioreactor are exactly intrinsic kinetics constants. The kinetics constants $v_{\max }$ and $K_{m}$ can be estimated by transforming integral form (4) into the following form:

$$
\frac{\ln \frac{S_{o}}{S}}{S_{o}-S}=\frac{v_{\max }}{K_{m}} \frac{t}{S_{o}-S}-\frac{1}{K_{m}}
$$

In order to investigate the Michaelis-Menten kinetic of ammonium removal on the immobilized microorganism on macro-porous carrier, the concentration varieties of ammonium along with time under conditions of DO $=2-3$ $\mathrm{mg} / \mathrm{L}$, temperature $=25-27^{\circ} \mathrm{C}, \mathrm{pH}=8.2-8.3$ were studied. The batch experimental results and related calculations are shown in Table II.

By biomass measured during operating bioreactor, average concentration of biomass was about $3.52 \mathrm{~g}$ microorganism $\mathrm{L}^{-1}$
$\mathrm{H}_{2} \mathrm{O}$, The value of $K_{m}$ and $v_{\max }$ are estimated to be $4.96 \mathrm{mg} \mathrm{L}^{-1}$ $\mathrm{H}_{2} \mathrm{O} 2.05 \mathrm{mg} \mathrm{L}^{-1} \mathrm{~s}^{-1}$. The constants for nitrification determined from our experiments are in good agreement with the literature.

The ammonium removal rates $v$ can be calculated by Michaelis-Menten equation $\quad\left(v_{m}=v_{\max } S /\left(K_{m}+S\right)\right) \quad$ and first-order kinetic $\left(v_{k}=k S\right)$. The characteristic relation between ammonium concentration $(S)$ and time $(t)$ can be described as third-order polynomial. The experimental ammonium removal rates $v_{e}$ could then easily be calculated from the derivative of the obtained polynomial. $v_{e}$ thus derived are compared to $v_{m}$ and $v_{k}$ in the last two columns of Table II. Good agreement is observed between $v_{e}$ and $v_{m}$. The relative errors of predicted and experimental nitrogen removal rate were less than $10 \%$ with the exception of the last two data. $v_{k}$ didn't agree with $v_{e}$ as well as $v_{m}$. It implies that Michaelis-Menten equation can better describe the ammonium removal kinetics in this system.

\section{Morphological Observation}

After operating the continuous experiment for 60 days, the microbial population and distribution in the microporous carrier was microscopically observed. Fig. 2a) shows the scanning electron micrograph of the microporous polyurethane foam carrier without microorganism present. The average aperture was $1 \mathrm{~mm}$ approximately, which conducive to gas and liquid pass through the microorganisms and accelerate metabolic activity due to the increase of microorganism density per unit volume. It can be seen from Fig. 2b) that a large number of microorganisms were observed in the macroporous carrier. Therefore, such a carrier structure can provide a good environment for microbial metabolism and proliferation. A further amplification (Fig. 2c) and (Fig. 2d) ) shows that many kinds of microorganisms were immobilized, such as filamentous, spherical bacteria and rod-shaped bacteria. The porous structure of the carrier can provide different microenvironments that meet the requirements of different micro-organisms for proliferation 
and nutrient.

\section{E. Performance of the Ammonium Removal Bioreactor}

The operational stability of immobilized mixed microorganisms in the continuous reactor was tested and the results are shown in Fig. 3. Within the first 4 days (hydraulic retention times $(\mathrm{HRT})=20 \mathrm{~h})$, the ammonium concentration of effluent stream decreased quickly to below $10 \mathrm{mg} \mathrm{L}^{-1}$. As HRT reduced to 16 hours, it rose to $16.9 \mathrm{mg} \mathrm{L}^{-1}$ and then decreased to $10 \mathrm{mg} \mathrm{L}^{-1}$ in the following two days. When HRT was reduced to 12 hours, it rose to about $15 \mathrm{mg} \mathrm{L}^{-1}$ and then reached a steady level. The volumetric load at last with HRT of $4 \mathrm{~h}$ was $0.24 \mathrm{~kg} \mathrm{~N} \mathrm{~m}^{-3} \mathrm{~d}^{-1}$ approximately. At the same time, nitrite and nitrate did not accumulated in the bioreactor. This may be attributed to different micro-environment of the carrier, which could achieve simultaneous nitrification and denitrification (see Fig. 3). There are two reasons could explain this phenomenon: first, due to diffusion restriction and oxygen requirement of nitrifying bacteria, the center of the carrier could be starved of oxygen; second, diffusion limitations within a large floc can also protect microorganisms from excess oxygen. The DO gradient in the carrier and floc can provide multi-entironments adapt to diversified microorganisms live with. So aerobic nitrification and anaerobic denitrification can simultaneously take place in a single reactor, which can promote the efficiency of nitrogen removal.



Fig. 3. The operational stability of immobilized mixed microorganisms in the continuous reactor containing ammonium as major contaminants.

\section{SUMMARY}

This study investigates the characteristic behavior of coimmobilizing microalgae and nitrifying bacteria onto microporous carrier and selects the optimum conditions, demonstrating that coimmobilization of microalgae and nitrifying bacteria has a potential in treating wastewater.

\section{ACKNOWLEDGMENT}

The authors gratefully acknowledge the support provided by National Natural Science Foundation of China (Grant No. 51308183), Natural Science Foundation of Jiangsu Province of China (Grant No. BK20130828), the Fundamental Research Funds for the Central Universities (2013B32214, 2014B07414) and A Project Funded by the Priority Academic Program Development of Jiangsu Higher Education Institutions. “ ”

\section{REFERENCE}

[1] R. Muñoz and B. Guieysse, "Algal-bacterial processes for the treatment of hazardous contaminants: A review," Water Research, vol. 40, pp. 2799-2815, June 2006.

[2] S. Aslan and I. K. Kapdan, "Batch kinetics of nitrogen and phosphorus removal from synthetic wastewater by algae," Ecological Engineering, vol. 28, pp. 64-70, Apr. 2006.

[3] K. Vijayaraghavan and Y. S. Yun, "Bacterial biosorbents and biosorption," Biotechnology Advances, vol. 26, pp. 266-291, Feb. 2008.

[4] L. E. Bashan, M. Moreno, J. P. Hernandez, and Y. Bashan, "Removal of ammonium and phosphorus ions from synthetic wastewater by the microalgae Chlorella vulgaris coimmobilized in alginate beads with the microalgae growth-promoting bacterium Azospirillum brasilense,' Water Research, vol. 36, pp. 2941-2948, July 2002.

[5] L. Yang, "Investigation of nitrification by co-immobilized nitrifying bacteria and zeolite in a batchwise fluidized bed," Water Science and Technology, vol. 35, pp. 169-175, June 1998

[6] J. Xiao, C. Zhu, D. Sun, P. Guo, and Y. Tian, "Removal of ammonium-N from ammonium-rich sewage using an immobilized Bacillus subtilis AYC bioreactor system," Journal of Environmental Sciences, vol. 23, pp. 1279-1285, Aug. 2011.

[7] Z. Y. Ji, J. S. Yuan, and X. G. Li, "Removal of ammonium from wastewater using calcium form clinoptilolite," Journal of Hazardous Materials, vol. 141, pp. 483-488, Mar. 2007.

[8] T. Willke and K. D. Vorlop, "Nitrification in PVAL beads: Influence of $\mathrm{pH}$ and temperature on nitrite oxidation," Prog. Biotechnol., vol. 11, pp. 718-724, June 1996.

[9] A. Sims, S. Gajaraj, and Z. Hu, "Nutrient removal and greenhouse gas emissions in duckweed treatment ponds," Water Research, vol. 47, pp. 1390-1398, Mar. 2013.

[10] G. Cao, Q. Zhao, X. Sun, and T. Zhang, "Characterization of nitrifying and denitrifying bacteria coimmobilized in PVA and kinetics model of biological nitrogen removal by coimmobilized cells," Enz. Micro. Tech., vol. 30, pp. 49-55, Jan. 2002.

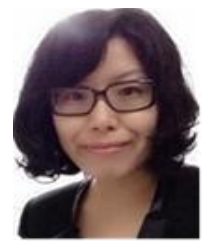

Xue Bai was born in China on March 28, 1982. From 2008 to 2010, she joint training her Ph.D. in environmental engineering, Peking University. From 2005 to June 2010, she combined her M.A.-Ph.D. in polymeric chemistry and physics, Lanzhou University. From September 2001 to June 2005, she got the B.A. in applied chemistry, Lanzhou University.

Currently, she is an associate professor in College of Environment, Hoha University. From July 2010 to June 2012, she is a post-doctor in School of Environment, Tsinghua University. Her research interests include catalyst synthesis, detection of environmental pollutants by nano-modified sensor, environmental behaviors of manufactured nanomaterials, advanced oxidation and photocatalytic degradation of persistent organic pollutants And she published some papers.

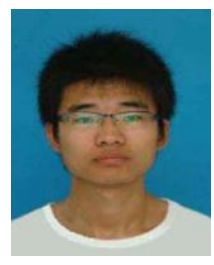

Haixin Gu was born in China on October 15, 1990. He studied at College of Environment, Hohai University since from 2013 to now. His major field of study includes water environmental chemistry and chemsensor.

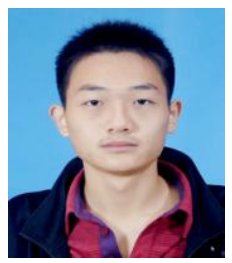

Yulong Li was born in China on September 12, 1991 $\mathrm{He}$ studied at College of Environment, Hohai University since from 2014 to now. His major field of study includes water environmental chemistry and environmental monitoring. 